\title{
特集 II「都市・住宅と防犯」にあたって
}

\section{Crime Prevention in Urban Areas and Residential Areas}

Takashi UEMATSU

日本の安全神話が崩れ，治安の悪化が懸念されている。わが国の安全神話を形成させて きたものは日本的なコミュニティによる無意識の相互監視であったが，コミュニティの弱 体化とともに，日本の伝統的な街づくりや設計が犯罪に対して脆いことを露呈し出してき ているといえよう。

そうした環境の変化に対応してわが国においても，かつての「犯罪が起きることをいか に防ぐか」という伝統的な防犯の考え方から「犯罪をいかに管理するか」という環境犯罪 学による犯罪予防の考え方がクローズアップされている。

そうした犯罪予防の考え方とわが国の街づくりへの応用可能性と課題については守山論 説で網羅的に紹介されている。玉川論説では場所と犯罪との関係について紹介されている。 山本論説は，最近の新築住宅に関する動きから，住宅の防犯環境設計の実際と課題を紹介 している。

渡論説では米国における事例から不動産価值の向上をインセンティブとした環境デザイ ンによる防犯の有効性が提言されている。

日本の住宅と住宅地における犯罪予防の問題の所在については，瀬渡論説が網羅的に紹 介し，実際の取組については集合住宅については河村論説，戸建住宅については町田論説 で紹介されている。

欧米流の「自らは自らが守る」という防犯思想にたった街づくり，住宅づくりが実際に 試みられている。反面，欧米においてはその行き過ぎによる副作用も指摘されている。 本特集が, 安全神話の崩れた今後の日本のまち, 住宅のあり方を考える一助となること を期待する。 